\title{
Effect of photochemical ageing on the ice nucleation properties of diesel and wood burning particles
}

\author{
C. Chou ${ }^{1, *}$, Z. A. Kanji $1^{1, * *}$, O. Stetzer ${ }^{1}$, T. Tritscher ${ }^{2,{ }^{* * *}}$, R. Chirico ${ }^{2,{ }^{* * * *}}$, M. F. Heringa ${ }^{2}$, E. Weingartner ${ }^{2}$, \\ A. S. H. Prévôt ${ }^{2}$, U. Baltensperger ${ }^{2}$, and U. Lohmann ${ }^{1}$ \\ ${ }^{1}$ ETH Zurich, Institute for Atmospheric and Climate Science, Switzerland \\ ${ }^{2}$ Laboratory of Atmospheric Chemistry, Paul Scherrer Institute, Villigen PSI, Switzerland \\ *now at: Science and Technology Research Institute, University of Hertfordshire, Hatfield, UK \\ *** now at: Air Quality Research Division, Environment Canada, Toronto, Canada \\ **** now at: TSI GmbH, Particle Instruments, Aachen, Germany \\ ***** now at: Italian National Agency for New Technologies, Energy and Sustainable Economic Development (ENEA), \\ UTAPRAD-DIM, Frascati, Italy
}

Correspondence to: C. Chou (c.chou@ @erts.ac.uk)

Received: 30 April 2012 - Published in Atmos. Chem. Phys. Discuss.: 8 June 2012

Revised: 28 November 2012 - Accepted: 12 January 2013 - Published: 22 January 2013

\begin{abstract}
A measurement campaign (IMBALANCE) conducted in 2009 was aimed at characterizing the physical and chemical properties of freshly emitted and photochemically aged combustion particles emitted from a log wood burner and diesel vehicles: a EURO3 Opel Astra with a diesel oxidation catalyst (DOC) but no particle filter and a EURO2 Volkswagen Transporter TDI Syncro without emission aftertreatment. Ice nucleation experiments in the deposition and condensation freezing modes were conducted with the Portable Ice Nucleation Chamber (PINC) at three nominal temperatures, $-30^{\circ} \mathrm{C},-35^{\circ} \mathrm{C}$ and $-40^{\circ} \mathrm{C}$. Freshly emitted diesel particles showed ice formation only at $-40^{\circ} \mathrm{C}$ in the deposition mode at $137 \%$ relative humidity with respect to ice $\left(\mathrm{RH}_{\mathrm{i}}\right)$ and $92 \%$ relative humidity with respect to water $\left(\mathrm{RH}_{\mathrm{w}}\right)$, and photochemical ageing did not play a role in modifying their ice nucleation behaviour. Only one diesel experiment where $\alpha$-pinene was added for the ageing process, showed an ice nucleation enhancement at $-35^{\circ} \mathrm{C}$. Wood burning particles also act as ice nuclei (IN) at $-40^{\circ} \mathrm{C}$ in the deposition mode at the same conditions as for diesel particles and photochemical ageing also did not alter the ice formation properties of the wood burning particles. Unlike diesel particles, wood burning particles form ice via condensation freezing at $-35^{\circ} \mathrm{C}$ whereas no ice nucleation was observed at $-30^{\circ} \mathrm{C}$. Photochemical ageing did not affect the ice nucleation ability of the diesel and wood burning particles
\end{abstract}

at the three different temperatures investigated but a broader range of temperatures below $-40^{\circ} \mathrm{C}$ need to be investigated in order to draw an overall conclusion on the effect of photochemical ageing on deposition/condensation ice nucleation across the entire temperature range relevant to cold clouds.

\section{Introduction}

Soot particles are solid, carbonaceous products resulting from incomplete combustion of materials such as coal, wood and other fossil fuels. Both wood burning particles from house heating or cooking and diesel car emissions contribute to a large fraction of particulate matter (PM) in the atmosphere. These combustion particles also consist of several types of volatile organic compounds (VOC) (McDonald et al., 2000; Schauer et al., 2001, 2002). Because combustion particles contain black carbon (BC), they warm the atmosphere by absorbing solar radiation thus reducing the amount of radiation reaching the surface. The reduction in surface heating and increase in heating aloft increases the static stability of the atmosphere and therefore tends to reduce convection and cloud formation (Denman et al., 2007). This change in cloudiness due to the decrease in near-cloud relative humidity and the increase in static stability caused by absorbing aerosol is called the semi-direct aerosol effect 
(Hansen et al., 1997) and has been observed in the Amazon region by Koren et al. (2004). However, Lin et al. (2006) showed for the same region that a high load of biomass burning could invigorate cloud formation. Recent field studies conducted at the high Alpine research station Jungfraujoch (Cozic et al., 2008; Targino et al., 2009) indicated that carbonaceous material is enriched in ice residuals with respect to the bulk aerosol. This is supported by the results from Ebert et al. (2011) who showed an enrichment in BC in the ice crystals sampled using a scanning electron microscope at the same research site. Nevertheless, the correlation between ice crystal concentration and $\mathrm{BC}$ enrichment is still unclear and more investigation is needed, as in a later campaign Kamphus et al. (2010) found that no BC enrichment was observable using a single particle mass spectrometer. Chou et al. (2011) have also shown that no correlation was found between IN number concentration and BC mass enrichment. In mid-level clouds, precipitation is generally initiated by the ice phase due to the Bergeron-Findeisen process. Lohmann and Hoose (2009) showed for example that a high concentration of $\mathrm{BC}$ particles could potentially lead to a faster glaciation of mixed phase clouds inducing earlier precipitation and resulting in a shorter cloud lifetime. Ice formation in clouds can take place via different heterogeneous processes which all involve the presence of a foreign particle termed ice nuclei (IN). Deposition, condensation, immersion and contact nucleation represent the four possible modes of ice nucleation in the atmosphere (Vali, 1985). Deposition nucleation occurs when ice deposits directly from the supersaturated vapour phase onto the IN. Condensation freezing refers to the condensation of supercooled liquid water on the IN followed by subsequent freezing of the droplet. Immersion freezing involves first the formation of a droplet around the IN, and upon cooling, the droplet freezes whereas contact freezing refers to the ice formation after the collision of a supercooled droplet with an interstitial solid aerosol.

The contribution of soot particles to deposition nucleation at temperatures above $-35^{\circ} \mathrm{C}$ is still unclear, as the onset of ice formation is very close to water saturation (DeMott et al., 1999; Möhler et al., 2005b,a; Dymarska et al., 2006). Furthermore, in the atmosphere, aerosol particles undergo a process called ageing which refers to different processes such as condensation of soluble materials and oxidized gases on the surface of the particles as well as surface reactions altering the particle chemical composition. These processes can affect the physical properties such as hygroscopicity, light scattering and absorption of the particles as well as their cloud formation ability. The review from Kärcher et al. (2007) summarized the main ice nucleation experiments performed on soot particles at cirrus level temperatures where three different types of soot were investigated (lamp black BC particles from Degussa Corporation, flame soot and graphite spark generated soot). In a temperature range from $-40^{\circ} \mathrm{C}$ to $-85^{\circ} \mathrm{C}$, the three different soot particles all showed different ice nucleation properties and graphite spark generated soot was found to be the most efficient ice nucleus in the deposition nucleation mode as it required lower relative humidity with respect to ice $\left(\mathrm{RH}_{\mathrm{i}}\right)$ to reach a $1 \%$ activated fraction. The $\mathrm{RH}_{\mathrm{i}}$ required for ice activation of untreated graphite spark soot range from $110 \%$ to $140 \%$ whereas other soot types required more than $140 \%$. More recent studies on biomass burning and soot particles using a continuous flow diffusion chamber have been performed at temperatures ranging from -30 to $-56^{\circ} \mathrm{C}$ (Petters et al., 2009; DeMott et al., 2009; Koehler et al., 2009; Friedman et al., 2011). Petters et al. (2009) showed that no deposition ice nucleation took place at $-30^{\circ} \mathrm{C}$ on the 21 types of fuel investigated. Immersion/condensation freezing was only seen on 21 out of 72 burns. Friedman et al. (2011) have investigated soot particles from -30 to $-40^{\circ} \mathrm{C}$ but did not observe any freezing at -30 and $-35^{\circ} \mathrm{C}$. At $-40^{\circ} \mathrm{C}$, the authors concluded that ice was formed due to homogeneous freezing. In this case, homogeneous freezing would describe the freezing of the particles upon water uptake, as the experiments are conducted below the homogeneous freezing temperature. DeMott et al. (2009) and Koehler et al. (2009) came to the same conclusion for experiments conducted between -46 and $-56^{\circ} \mathrm{C}$ on biomass burning and different types of soot, respectively.

It has also been shown that a sulphuric acid coating on soot particles reduced the ice nucleation efficiency in the temperature range of $-40{ }^{\circ} \mathrm{C}$ to $-85^{\circ} \mathrm{C}$ in the deposition mode (Möhler et al., 2005a). Möhler et al. (2005b) showed that a higher organic carbon (OC) content in a soot particle decreases the IN ability at $-65^{\circ} \mathrm{C}$ by an ice saturation ratio of 0.25 (from 1.45 to 1.7 ). These studies infer that modification of the surface properties of soot particles can have a direct effect on their ice nucleation ability. Hoose et al. (2008) and Storelvmo et al. (2008) showed that if the coating has the ability to de-activate some IN as it was shown in the study of Möhler et al. (2005b) with sulphuric acid, this would lead to a lower frequency of cloud glaciation, a delay in precipitation formation and thus a longer cloud life time. The result is an increase in cloud albedo leading to a cooling of the surface.

In addition, previous studies on mineral dust have shown that organic coating led to a decrease in ice nucleation efficiency (Möhler et al., 2008; Sullivan et al., 2010). The IMpact of Biomass burning AerosoL on Air quality aNd ClimatE (IMBALANCE) project aimed to characterize the physical and chemical properties of aged and non aged biomass burning particles from wood and combustion particles from diesel cars. The measurement campaign took place at the Paul Scherrer Institute's smog chamber from $17 \mathrm{Au}-$ gust to 15 October 2009, in Villigen, Switzerland. Ice nucleation experiments took place from 17 August to 23 September 2009. So far, no ice nucleation measurements on the effect of photochemical ageing onto wood burning and diesel soot have been reported in the literature as previous coating studies have been performed with laboratory soot generators and were not representative of soot particles found in the 
Table 1. Summary of the diesel experiments. The experiment number refers to the ones used in Chirico et al. (2010).

\begin{tabular}{ccccc}
\hline $\begin{array}{c}\text { Experiment } \\
\text { number }\end{array}$ & $\begin{array}{c}\text { date } \\
\text { (dd.mm.yyy) }\end{array}$ & comments & $\begin{array}{c}\text { mean mobility } \\
\text { diameter range }\end{array}$ & $\begin{array}{c}\text { OC: BC for } \\
\text { fresh exhaust }\end{array}$ \\
\hline $\begin{array}{c}\text { EURO3, Opel Astra, with DOC, } \\
\text { idle conditions }\end{array}$ & $17 / 08 / 2009$ & warm idle & 100 to $160 \mathrm{~nm}$ & 0.12 \\
\hline 8d & $19 / 08 / 2009$ & cold idle & 80 to $160 \mathrm{~nm}$ & n.a. \\
9d & $21 / 08 / 2009$ & cold idle & n.a. & n.a. \\
10d & $26 / 08 / 2009$ & cold idle & 80 to $160 \mathrm{~nm}$ & n.a. \\
\hline 11d & & & \\
\hline EURO2, VW Transporter, without \\
after-treatment, idle conditions
\end{tabular}

atmosphere. This paper discusses the ice nucleation properties of fresh and photochemically aged diesel and wood combustion particles.

\section{Experimental setup}

The PSI smog chamber is a $27 \mathrm{~m}^{3}(3 \times 3 \times 3 \mathrm{~m})$ flexible bag made of $125 \mu \mathrm{m}$ thickness DuPont Teflon fluorocarbon film (FEP, type 500A, Foiltec GmbH, Germany). The Teflon bag is temperature controlled by two cooling units that keep the temperature between 20 and $25^{\circ} \mathrm{C}$. Diesel and wood burning emission particles are injected into the smog chamber, where they can be characterized. Solar radiation was simulated by four xenon arc light sources. The chamber is equipped with several instruments to monitor the particle and the gas phase during an experiment. More details about the PSI smog chamber are given in Paulsen et al. (2005). The experimental setup used during the PSI IMBALANCE campaign 2009 is shown in Fig. 1 and the complete overview for the diesel and wood burning experiments can be found in Chirico et al. (2010) and Heringa et al. (2011), respectively.

\subsection{Methodology}

During the measurement period, diesel experiments took place from 17 August to 4 September 2009 where two diesel vehicles were used as emission sources. A EURO3 Opel Astra with a diesel oxidation catalyst (DOC) but no particle filter was used to produce soot particles from 17 until 26 August. From 31 August to 4 September, a EURO2 Volkswagen Transporter TDI Syncro without emission aftertreatment was used. More details about the source emission conditions are given in Table 1.
Wood burning experiments took place from 9 to 23 September 2009. A modern log wood burner was used during this period in order to reproduce the emissions resulting from house heating. It was possible to sample and investigate three phases: the starting, flaming and smoldering phase. The latter was not investigated during this study as it is primarily gas phase. The starting phase refers to particles that were directly sampled from the chimney after the wood started to burn. The flaming phase corresponds to particles which were injected after the wood was completely flaming. Table 2 summarizes the days and conditions of each experiments.

Generated particles were sampled through a dilution system in order to reduce the total number concentration of particles produced. The dilution system was heated to $150^{\circ} \mathrm{C}$ to keep the combustion products close to the temperature of the car or chimney exhaust before injecting them into the smog chamber in order to avoid condensation of VOCs that resulted from the combustion. Low dilution ratios overestimate the emitted fine particle mass because at low dilution ratios less evaporation occurs for some particle-associated organics (Robinson et al., 2007). The mass of PM emitted by diesel engines with no aftertreatment devices can decrease with increasing dilution ratio. This mass reduction is associated with semi-volatile organic compounds that repartition into the gas phase with increasing dilution (Lipsky and Robinson, 2006).

Products resulting from the combustion are mainly black carbon (BC), OC and VOCs. Note that another abundant compound present in diesel vehicle emissions (and not in wood burning emissions) is NO. Primary particles were characterized for 1 to $2 \mathrm{~h}$ before triggering photochemical reaction. In the case of the diesel experiments, ozone was first injected in order to accelerate the depletion of $\mathrm{NO}$ to form $\mathrm{NO}_{2}$. The four xenon arc lights were then switched on to 
Table 2. Summary of the wood burning experiments. The experiment number refers to the ones used in Heringa et al. (2011).

\begin{tabular}{ccccc}
\hline $\begin{array}{c}\text { Experiment } \\
\text { number }\end{array}$ & $\begin{array}{c}\text { date } \\
\text { (dd.mm.yyy) }\end{array}$ & comments & $\begin{array}{c}\text { mean mobility } \\
\text { diameter range }\end{array}$ & $\begin{array}{c}\text { OC : BC for } \\
\text { fresh exhaust }\end{array}$ \\
\hline Modern log wood burner & & & & \\
\hline $11 \mathrm{w}$ & $09 / 09 / 2009$ & flaming phase & 110 to $140 \mathrm{~nm}$ & 0.05 \\
$12 \mathrm{w}$ & $11 / 09 / 2009$ & flaming phase & 150 to $200 \mathrm{~nm}$ & 0.08 \\
$13 \mathrm{w}$ & $16 / 09 / 2009$ & flaming phase & 180 to $270 \mathrm{~nm}$ & 0.08 \\
$15 \mathrm{w}$ & $21 / 09 / 2009$ & starting phase & 140 to $220 \mathrm{~nm}$ & 0.99 \\
$16 \mathrm{w}$ & $23 / 09 / 2009$ & starting phase & 100 to $160 \mathrm{~nm}$ & 0.65 \\
\hline
\end{tabular}

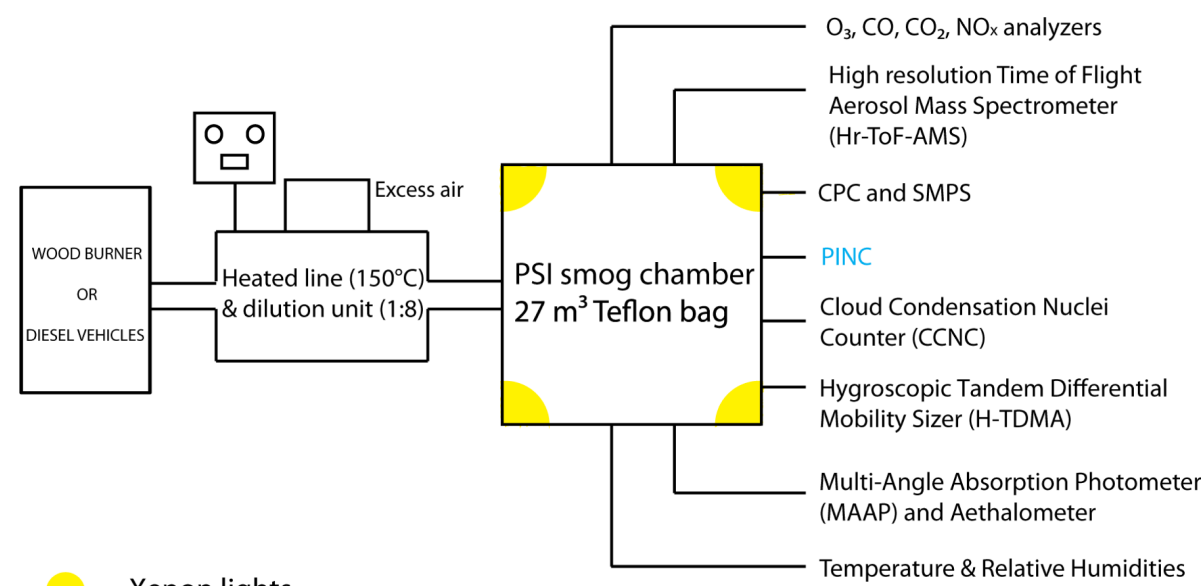

Xenon lights

Temperature \& Relative Humidities

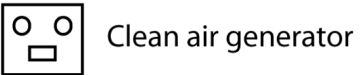

Fig. 1. Experimental setup during the IMBALANCE campaign, 2009.

simulate solar radiation and oxidized the VOCs. Propene was introduced to have a favourable $\mathrm{NO}_{2}$ to $\mathrm{VOC}$ ratio to form radicals and avoid formation of nitric acid $\left(\mathrm{HNO}_{3}\right)$. Soot particles are coated via condensation of the oxidized VOCs from their own gas phase. Due to the very low content of NO from wood combustion, neither ozone or propene needed to be injected into the smog chamber. Lights were switched on to trigger photochemical reactions after the characterization of primary particles. Note that $\alpha$-pinene was injected as additional VOC during only one experiment (15d) after $5.5 \mathrm{~h}$ of lights on to create a thicker coating to the particles.

The $\mathrm{BC}$ concentrations were measured and derived by two different instruments: an aethalometer (AE31, Magee Scientific Company, Berkeley, CA) that collects particles on a quartz filter and measured the attenuation of light through the filter at different wavelengths. BC concentration was derived from the $880 \mathrm{~nm}$ attenuation coefficient using a mass specific attenuation cross section of $16.6 \mathrm{~m}^{2} \mathrm{~g}^{-1}$ and an empirical correction for the shadowing effect (Weingartner et al., 2003). A multi-angle absorption photometer (MAAP, Model 5012, Thermo Fischer Scientific) was simultaneously measuring the light scattering and absorption properties of the particles collected on a glass fibre filter. BC concentrations were calculated using a mass specific cross section of $6.6 \mathrm{~m}^{2} \mathrm{~g}^{-1}$ at a wavelength of $630 \mathrm{~nm}$. More details on the particulate organic mass and black carbon measurements are given in Chirico et al. (2010) and Heringa et al. (2011). A High Resolution Time-of-Flight Aerosol Mass Spectrometer (HR-ToF-AMS) was used to measure OM to OC ratio where the $\mathrm{OC}$ concentrations were derived using the procedure as described in Aiken et al. (2008). Size distributions of the particles were measured with a Scanning Mobility Particle Sizer (SMPS, TSI Model 3071) from which the mean mobility diameter of the particles was derived. Note that due to the fractal geometry of soot particles, freshly emitted particles mobility size may be significantly different from their actual size. More information about the particle hygroscopicity measurements can be found in Tritscher et al. (2011) and Martin et al. (2012).

\subsection{IN measurements}

Ice nuclei measurements of polydisperse diesel and wood burning particles were performed with the Portable Ice 
Nucleation Chamber (PINC) which was connected downstream of the PSI smog chamber (see Fig. 1). Briefly, the instrument consists of two parallel vertical plates with a spacing of $10 \mathrm{~mm}$ which can be individually temperature controlled. The inner walls are coated with a thin layer of ice and set at a similar temperature before a measurement is conducted. Aerosols are then sampled at a flow of 1 liter per min (lpm) between two dry particle-free sheath air layers $(4.5 \mathrm{Lpm}$ each). The difference between the warm and cold plate temperature is then progressively increased to create a supersaturation profile between the two walls. A higher temperature difference produces a higher supersaturation that the particles are exposed to. Ice crystals are detected by their larger size (relative to the aerosol particles sampled) with an optical particle counter (OPC, CLIMET 3100). Above water saturation in the growth section of PINC, particles that form water droplets will evaporate before they are sampled by the OPC due to the presence of an evaporation section held at water sub-saturation, upstream of the OPC. However, above a certain supersaturation with respect to water, the residence time of the particles in the evaporation section is not long enough to evaporate the droplets. This limit is termed as the droplet survival line where ice crystals cannot be differentiated from water droplets by their size alone. Is it important to mention for the rest of the discussion that all the data points above the droplet survival line can not be interpreted as ice crystals. A detailed description of PINC can be found in Chou et al. (2011). PINC is able to measure quantitatively ice nucleation in the deposition mode when the relative humidity with respect to water $\mathrm{RH}_{\mathrm{w}}$ at the sample position is below $100 \%$ and condensation freezing when $\mathrm{RH}_{\mathrm{w}}$ is between $100 \%$ and the droplet survival line. Nevertheless, in the latter case, it is difficult to distinguish the fraction of ice crystals formed via condensation freezing if deposition was already occurring at lower RH. If no ice formation was observed before water saturation, we attribute the ice formation at water supersaturated conditions to condensation freezing.

It has been shown by previous studies (DeMott et al., 1999; Möhler et al., 2005b,a; Dymarska et al., 2006) that deposition ice nucleation onto soot particles is not observed at temperatures above $-30^{\circ} \mathrm{C}$. Therefore, the ice nucleation ability of combustion particles in this study was investigated at three nominal temperatures, $-30^{\circ} \mathrm{C},-35^{\circ} \mathrm{C}$ and $-40^{\circ} \mathrm{C}$. The uncertainties in the calculated $\mathrm{RH}_{\mathrm{w}}$ at water saturation for this sampling temperature range is on the order of $3 \%$ of $\mathrm{RH}_{\mathrm{w}}$.

\section{Results and Discussion}

Investigation of the ice nucleation properties of two different types of diesel vehicles emission particles was conducted (following the EURO3 and EURO2 norms). More information on these norms can be found at http://europa.eu/legislation_summaries/environment/ air_pollution/index_en.htm. Figure 2 shows the different

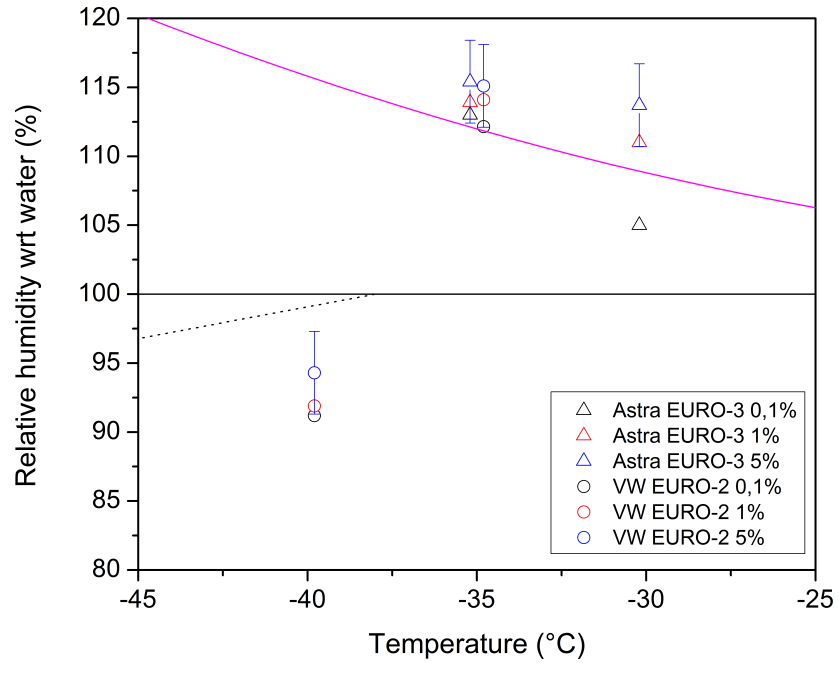

Fig. 2. Relative humidity with respect to (wrt) water as a function of temperatures at which different ice fraction are detected: $0.1 \%, 1 \%$ and $5 \%$ activated fraction for EURO-2 and EURO-3 diesel vehicles. The magenta line represents the droplet survival line above which ice and water cannot be distinguished by the OPC alone. Data points above this line can not be attributed to ice. The dotted line represents the homogeneous freezing threshold for $200 \mathrm{~nm}$ supercooled ammonium sulphate solution droplets based on the parameterizations of Koop et al. (2000)

RH conditions at which we observed ice active fractions $(0.1 \%, 0.5 \%$ and $1 \%)$ of freshly emitted diesel particles as a function of temperature and vehicle type. This comparison has also been done for wood burning particles (but only for the photochemically aged due to the few available data of the freshly emitted particles) sampled from the starting and flaming phase. In Fig. 3 the results for $0.1,1$ and $5 \%$ ice active fractions as a function of temperature are shown. It is crucial to mention for the rest of the discussion that the ice active fractions are normalized to the particles with a diameter larger than $50 \mathrm{~nm}$ in order to remove the contribution from nucleation mode particles that form in the photochemical process. We note that there is no significant difference between the ice activity of the starting and the flaming phase. Due to similar ice nucleation properties of the different vehicle types and wood burning phases, we decided for the rest of the discussion to average the values of both types of vehicles emission for the diesel experiments and to also average the values for both phases of the wood burning experiments in order to facilitate the discussion on the photochemical effect at different temperatures.

\subsection{Ice nucleation ability of diesel particles}

The ice nucleation results of fresh and photochemically aged diesel particles are shown in Fig. 4 . At $-35^{\circ} \mathrm{C}$, we conclude that no detectable ice nucleation is taking place since the $0.1 \%$ activated fraction appears above the droplet survival 


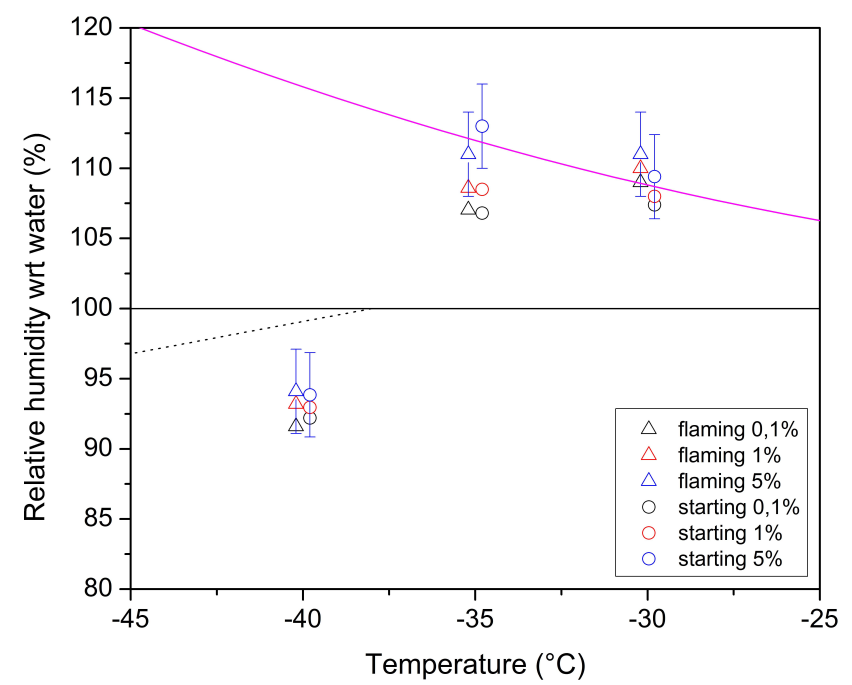

Fig. 3. Same as Fig. 2 but for wood burning particles in both the starting and flaming phase.

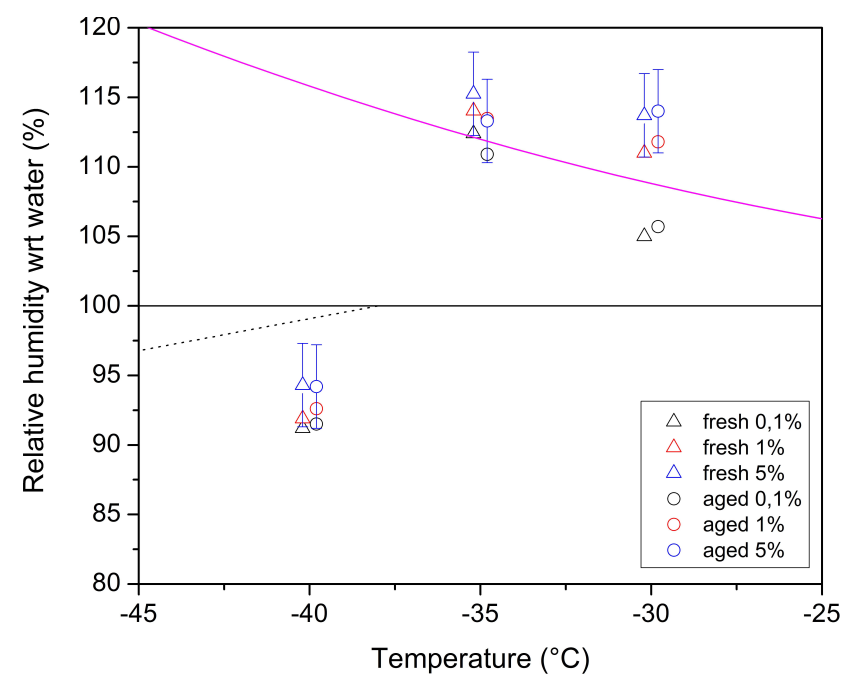

Fig. 4. Ice onset relative humidity for deposition/condensation freezing as a function of temperature for the given ice active fractions. Data shown are for fresh and photochemically aged diesel particles. The rest is the same as Fig. 2.

line. At $-30{ }^{\circ} \mathrm{C}$, the $0.1 \%$ activated fraction is detectable below the droplet survival line but due to the uncertainty on the $\mathrm{RH}_{\mathrm{w}}$ within PINC, it is not possible to conclude here that ice was observed. Having a lower ice detection limit, i.e. $0.01 \%$ would allow us to draw a better conclusion, but the background in PINC with the aerosol concentration encountered during the campaign is very close to $0.01 \%$, thus we can only conclude that no ice formation was taking place due to the $\mathrm{RH}_{\mathrm{w}}$ uncertainty. At $-40^{\circ} \mathrm{C}$, ice formation occurs below water saturation via deposition nucleation at $137 \% \mathrm{RH}_{\mathrm{i}}$ and $92 \% \mathrm{RH}_{\mathrm{w}}$. Figure 5 shows a comparison of our results to previous studies involving graphite spark soot for an ice

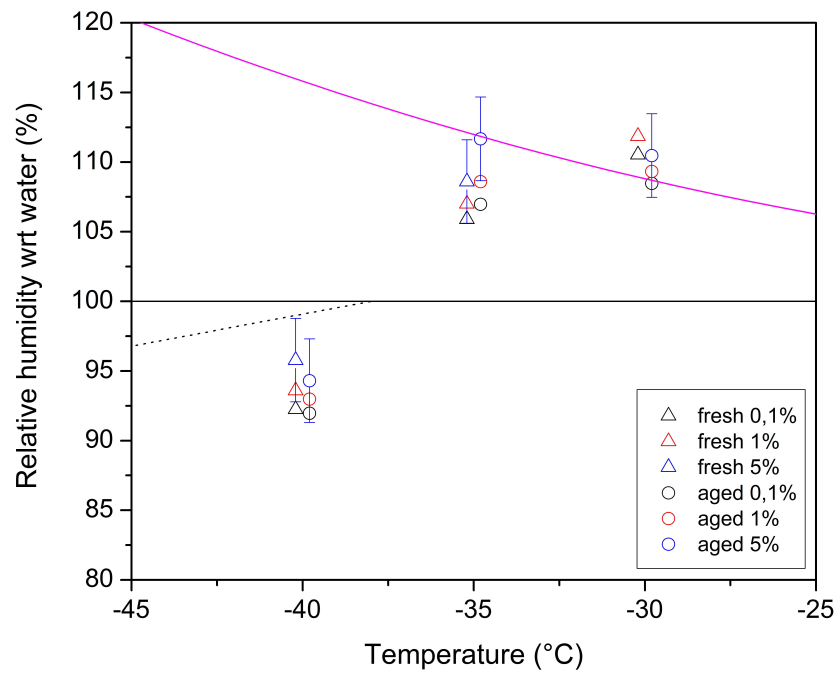

Fig. 5. Same as Fig. 4 but for fresh and photochemically aged wood burning particles. The data points for the fresh particles are an average of the starting and flaming phase (shown in Fig. 3).

active fraction of $0.1 \%$. Our results are comparable to Kanji et al. (2011) within experimental uncertainties of $\mathrm{RH}_{\mathrm{w}}$, despite not being at identical but comparable temperatures. The results in Möhler et al. (2005b) show a more efficient ice activation compared to our observations. One of the main reason for this difference is the longer residence time in the AIDA compared to CFDC instruments (several minutes compared to 8 and 12 seconds in PINC and the University of Toronto CFDC, respectively). The other reason when reaching water saturation is that due to the shorter residence time of the particles in the CFDC, higher $\mathrm{RH}_{\mathrm{w}}$ are required to form water droplets inducing condensation freezing. In Möhler et al. (2005b), $\mathrm{RH}_{\mathrm{w}}$ values above $100 \%$ do not take place since the aerosols act as $\mathrm{CCN}$ and restrict the supersaturation to reach higher values like in the real atmosphere.

Photochemical ageing of particles did not influence the ice nucleation properties. Furthermore, at $-40^{\circ} \mathrm{C}$, ice nucleation onto aged particles took place at similar relative humidities to non aged particles. This similarity may be explained by the fact that throughout these experiments, the organic coating onto the diesel particles was not thick enough to de-activate or enhance the ice nucleation properties of the aerosol. It is also possible due to the chain like shape of soot that the coating was not uniform and that some spots on the particles were not coated and thus no change in IN ability was observed.

Figure 7 a shows the ice activated fraction of aged diesel particles of experiment $15 \mathrm{~d}$ at different times of the experiment. Ice nucleation was not observed after photochemical ageing, but was observed at $-35^{\circ} \mathrm{C}$ in the condensation freezing mode after addition and photochemical reaction of $\alpha$-pinene, which infers that either the chemical composition or the particle size change is enhancing the IN ability of the particles. This also suggests the likelihood of a thicker and 


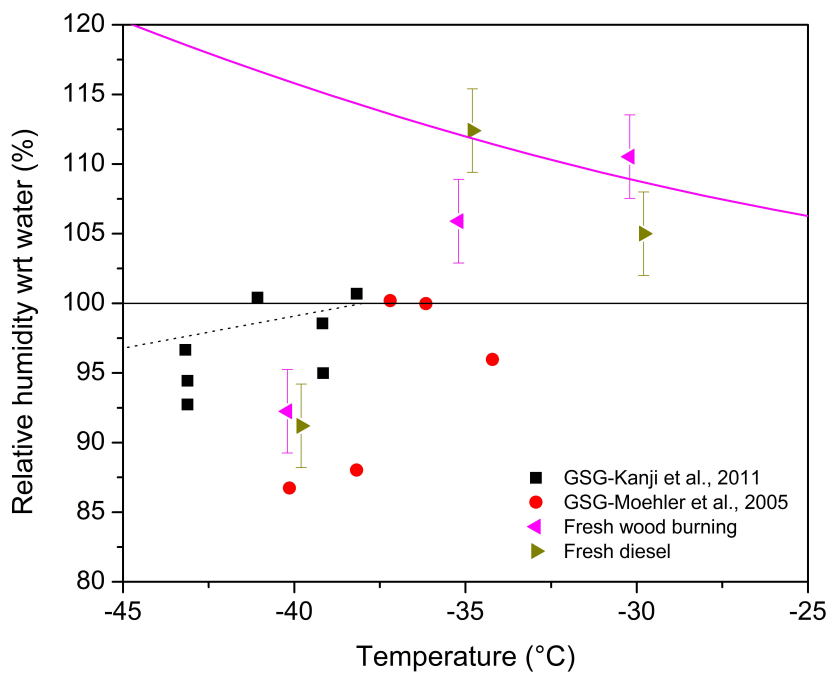

Fig. 6. Ice active fraction $(0.1 \%)$ of graphite spark soot and fresh diesel and wood burning particles. The data points from Möhler et al. (2005b) are from the AIDA chamber experiments in Karlsruhe, Germany. Those from Kanji et al. (2011) are from the University of Toronto continuous flow diffusion chamber. The magenta and dotted lines represent the same parameters as in Fig. 4. Note that the magenta line is only valid for the wood burning and diesel particles data points.

more uniform coating distribution around the particles. Figure $7 \mathrm{~b}$ shows the mean mobility diameter derived from the SMPS measurements throughout experiment $15 \mathrm{~d}$, and it is noticeable that after $\alpha$-pinene was added the mean diameter substantially increased confirming that the size of the particle possibly plays a role in the IN ability enhancement. Therefore it should be noted that the mean diameter of the particles used in the two experiments shown in Fig. 7a are substantially different. The experiment that did not show any ice nucleability (3-h aged) had a mean particle size of $\approx 120 \mathrm{~nm}$ while the particles aged after the addition of $\alpha$-pinene that showed an enhanced ice nucleability had particles with a mean diameter of $175 \mathrm{~nm}$. Regarding the chemical composition, the $\mathrm{OC}$ : $\mathrm{BC}$ ratio also increased from 0.7 to 1.58 , after addition of $\alpha$-pinene. The effect of the size and the OC : BC ratio on the IN ability are discussed more in detail in Sect. 3.3.

\subsection{Ice nucleation ability of wood burning particles}

Figure 5 shows the ice nucleation ability of freshly emitted and photochemically aged wood particles. At $-30^{\circ} \mathrm{C}$, no detectable ice nucleation can be inferred. This result is in agreement with the study from Petters et al. (2009) where biomass burning of several grasses and wood types were investigated at $-30^{\circ} \mathrm{C}$ and did not show any detectable ice crystal formation. Unlike diesel particles, at $-35^{\circ} \mathrm{C}$ wood burning particles show significant ice formation in the condensation freezing mode. The effect of coating seems to decrease the ice nu- cleation ability of the particles but is similar to the uncoated particles within the uncertainties in RH of PINC $( \pm 3 \%)$. At $-40^{\circ} \mathrm{C}$, deposition nucleation takes place on both fresh and aged wood burning particles at similar relative humidity conditions $\left(\mathrm{RH}_{\mathrm{w}} \approx 92-96 \%\right)$ with the aged particles activating at systematically lower $\mathrm{RH}_{\mathrm{i}}$ but again within the experimental uncertainty. These conditions are also similar to those at which fresh and aged diesel particles trigger ice nucleation and thus also similar to graphite spark generated soot (Möhler et al., 2005b; Kanji et al., 2011). This raises the question if there is a unique relative humidity threshold for when polydisperse soot and biomass burning particles may act as ice nuclei in the deposition nucleation mode? This is discussed in more detail in Sect. .4.

\subsection{Comparison between wood and diesel particles}

Our study has shown that photochemical ageing of wood burning and diesel particles with its own VOC gas phase has no observable effect on the ice nucleation ability of the particles, except in experiment $15 \mathrm{~d}$ where a thick organic coating of oxidized $\alpha$-pinene was present. It is not fully understood as to why wood burning particles are more ice active at $-35^{\circ} \mathrm{C}$ compared to diesel particles. In order to explain this behaviour, the $\mathrm{OC}: \mathrm{BC}$ ratio in our work was investigated because Möhler et al. (2005b) showed that the OC: BC ratio of the particles is an important parameter to consider for IN properties of soot particles. The evolution of the OC: BC ratio of diesel experiments is shown in Fig. 8. The ratio is approximately 0.10 for the Opel Astra, whereas the VW transporter showed higher values between 0.2 to 0.4 after turning the smog chamber's xenon lights on. The only exception is in experiment $15 \mathrm{~d}$, where a large amount of OC was produced after photochemistry and values up to 0.7 were reached. Note that in experiment $15 \mathrm{~d}$, no exhaust aftertreatment devices were used. More details about the organic matter $(\mathrm{OM})$ variations are discussed in Chirico et al. (2010), and are not the focus of this paper. Nevertheless, no ice nucleation was observed at an $\mathrm{OC}: \mathrm{BC}$ ratio of 0.7 , and could only be observed when the sizes of the particles as well as the $\mathrm{OC}$ : $\mathrm{BC}$ ratio increased (from a mean diameter of $125 \mathrm{~nm}$ to $175 \mathrm{~nm}$ and from an $\mathrm{OC}: \mathrm{BC}$ of 0.7 to above 1.5). In comparison, the $\mathrm{OC}: \mathrm{BC}$ ratio of wood burning particles shows different behaviours depending on the phase sampled as is depicted in Fig. 9. For the flaming phase experiments, the $\mathrm{OC}: \mathrm{BC}$ ratio varies between 0.1 to 0.5 which is in the same range as the diesel experiments. Nevertheless, ice nucleation was observed for those experiments at $-35^{\circ} \mathrm{C}$ whereas no ice was formed for the diesel experiments. Indications that the $\mathrm{OC}: \mathrm{BC}$ ratio is not playing an important role in the ice nucleation efficiency are also confirmed by the starting phase experiments, which show an ice nucleation behaviour similar to the flaming phase experiments, but with an $\mathrm{OC}$ : $\mathrm{BC}$ ratio above 2 .

Investigation of the functional groups by using the combination of a scanning transmission X-ray microscopy (STXM) 


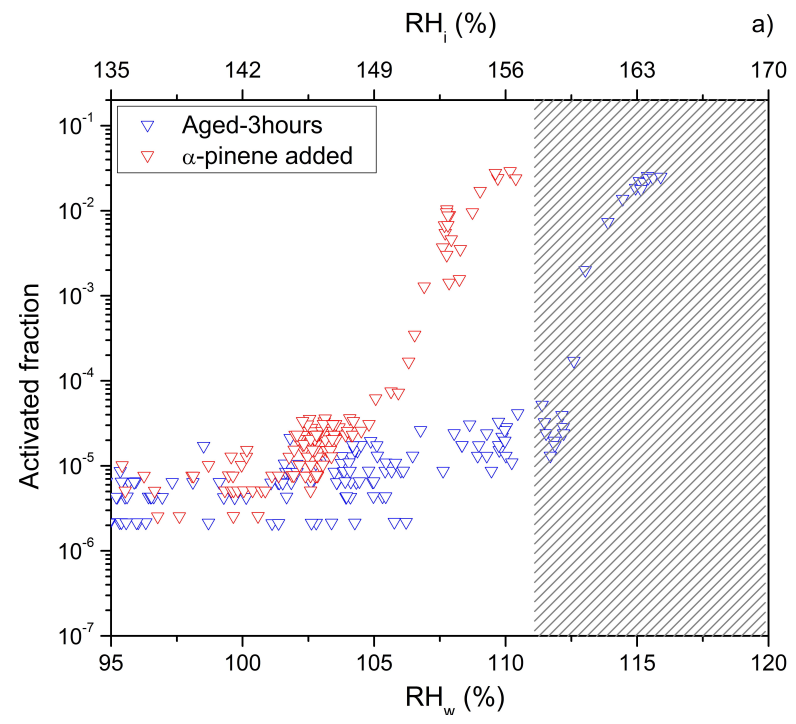

a)

Experiment 15d

b)

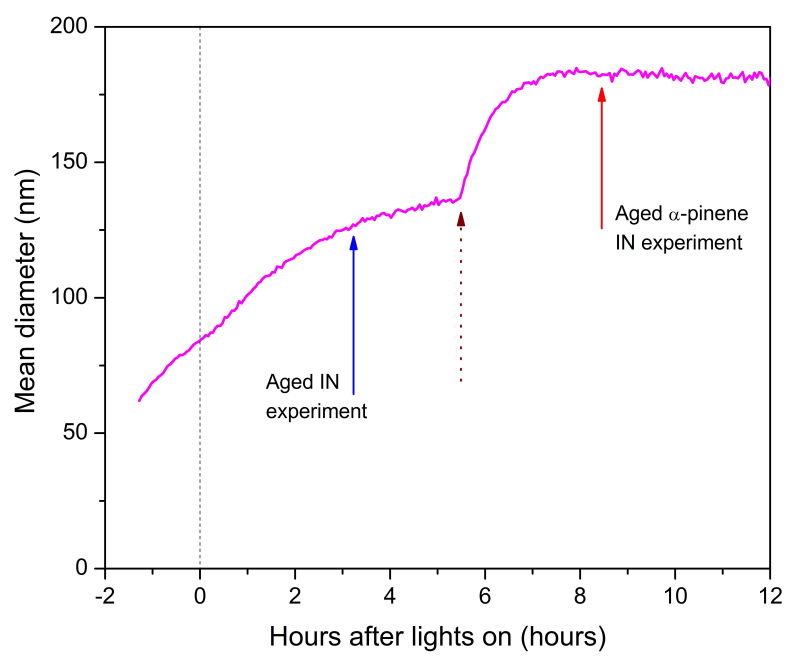

Fig. 7. (a) Ice nucleation activated fraction as a function of saturation ratio with respect to ice and water of photochemically aged diesel particles and diesel particles coated with $\alpha$-pinene at $-35^{\circ} \mathrm{C}$. The shaded area represents the region where the OPC cannot distinguish between ice crystals and water droplets. (b) Mean diameter evolution throughout experiment $15 \mathrm{~d}$. Solid arrows represent the time where the IN measurements took place and the dotted arrow represent the time when $\alpha$-pinene was added. The dashed vertical black line represents the moment when lights were turned on.

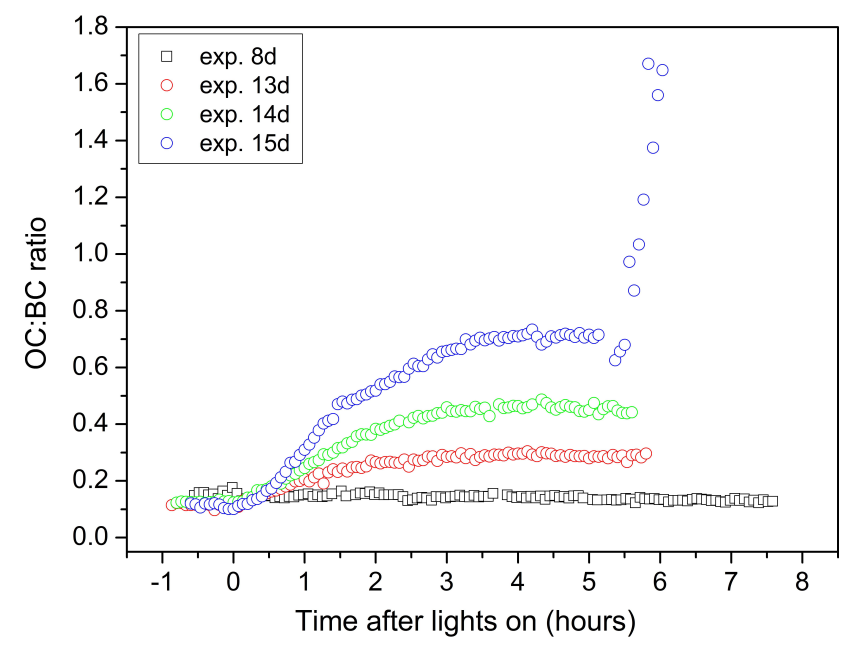

Fig. 8. OC to BC ratio evolution throughout several hours for four diesel experiments. The square symbol represents experiments with the Opel Astra. Circles represent experiments with the VW Transporter. Note that in experiment $15 \mathrm{~d}$, oxidized $\alpha$-pinene was used for the coatings after 5.5 hours of lights on.

and near edge X-ray absorption fine structure (NEXAFS) spectroscopy was done for some of the experiments and the results are reported in Zelenay et al. (2011). Functional groups of aged and untreated wood burning particles show very few differences whereas an increase in carboxylic carbon from oxidized organic compounds is reported. This means that in the different ice nucleation experiments with diesel, the modification of the functional groups at the sur-

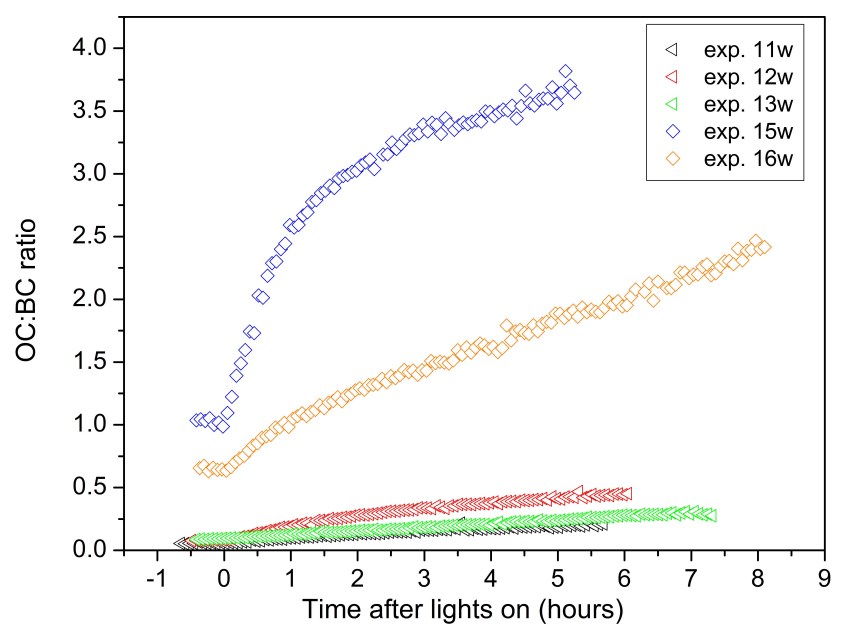

Fig. 9. OC to BC ratio evolution throughout several hours for five wood burning experiments. Triangles correspond to flaming phase experiments. Diamonds correspond to starting phase experiments.

face of the particles did not modify their ice nucleation properties. No STXM-NEXAFS analysis have been performed on particles coated with $\alpha$-pinene, so the better ice nucleation of these particles cannot totally be attributed to the increase in size.

One explanation for the differences in the ice nucleation behaviour at $-35^{\circ} \mathrm{C}$ between wood burning and diesel particles could be attributed to a generally larger average size of the wood burning particles compared to diesel particles and a broader size distribution which could explain why for 
a similar $\mathrm{OC}$ : $\mathrm{BC}$ ratio, only wood burning particles formed ice at $-35^{\circ} \mathrm{C}$. Another explanation could be the different chemical composition of the products resulting from wood combustion. It is known for example that emissions from wood pellets burning show a higher fraction of fly ash which have better ice nucleation activity than soot particles (Fornea et al., 2009).

\subsection{Homogeneous or heterogeneous ice formation?}

An interesting feature of Fig. 7 is the steepness of the activation curve that was found in all the experiments at $-40^{\circ} \mathrm{C}$ for diesel and wood burning particles, as well as wood burning experiments at $-35^{\circ} \mathrm{C}$. Recently Friedman et al. (2011) assumed in their experiment that the ice crystals observed at $-40^{\circ} \mathrm{C}$ are formed via homogeneous nucleation. Our experiments showed some similar behaviour with an ice activation of $0.1 \%$ starting at around a $\mathrm{RH}_{\mathrm{i}}$ of $137 \%$ and $\mathrm{RH}_{\mathrm{w}}$ of $92 \%$ at $-40^{\circ} \mathrm{C}$ for both wood and diesel particles. The true nature of the mechanism that is occurring is however uncertain as ice was observed at RH conditions below the predicted homogeneous nucleation line (as is evident in Fig. 3) for a $200 \mathrm{~nm}$ ammonium sulphate (AS) particle (Koop et al., 2000). Furthermore, due to the non-hygroscopic nature of the particles investigated (Tritscher et al., 2011; Martin et al., 2012) and the absence of soluble material, the hypothesis of homogeneous nucleation taking place below the predicted homogeneous nucleation threshold for AS is difficult to prove. It however can not be ruled out as Koop (2004) has shown that at these high temperatures the uncertainty in $\mathrm{RH}_{\mathrm{w}}$ could be in the order of $2.5 \%$. Therefore, further investigations to understand the exact mechanism are required in future experiments. As no clear results points towards one or the other, we consider our results to indicate deposition nucleation.

\subsection{Comparison with mineral dust}

Figure 10 shows a comparison of the IN activity of the particles investigated during IMBALANCE to different mineral dust types. It is observed that fresh diesel and wood burning particles require higher supersaturation to reach a $0.1 \%$ activated fraction for the temperature range from $-30^{\circ} \mathrm{C}$ to $-40^{\circ} \mathrm{C}$. At $-40^{\circ} \mathrm{C}$ Arizona test dust (ATD) and Canary Island dust (CID) reach the $0.1 \%$ ice active fraction at much lower $\mathrm{RH}_{\mathrm{w}}$ (by 10 to $25 \%$ ). Furthermore, deposition nucleation takes place at temperatures as warm as $-30^{\circ} \mathrm{C}$ and close to water saturation on ATD, CID and Saharan dust (SD). Such high freezing temperatures are not observed on either diesel or wood burning particles at $-30^{\circ} \mathrm{C}$ and $-35^{\circ} \mathrm{C}$ as they either form ice via condensation freezing or did not form detectable ice crystals as discussed in previous sections. Note that no information on the ice formation mechanism and conditions required are available for Israeli dust (ID) as no experiments below $-30^{\circ} \mathrm{C}$ had been conducted. It is

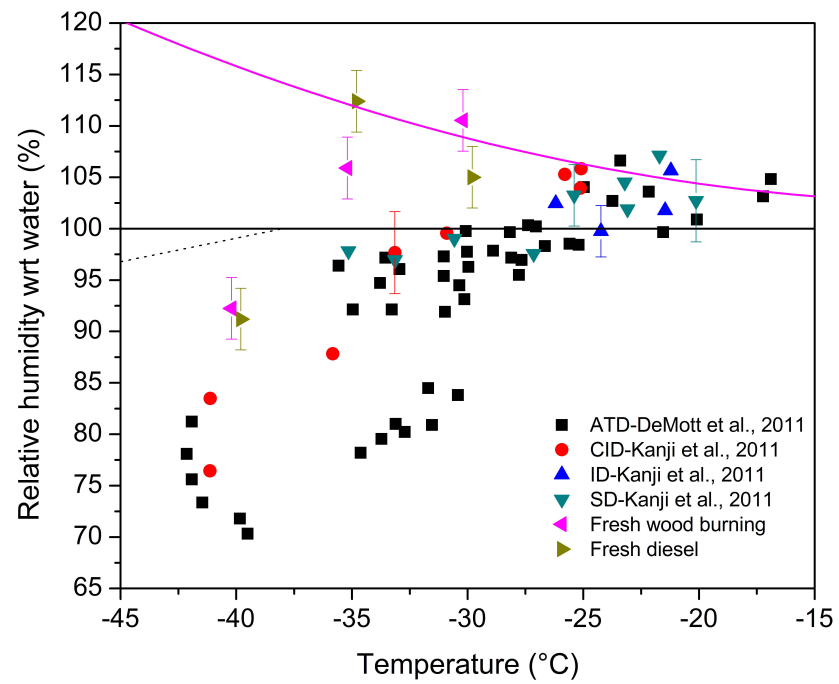

Fig. 10. Comparison of $0.1 \%$ ice active fraction of different mineral dust and fresh diesel and wood burning particles. The data points from Demott et al. (2011) are from different IN chambers. Those from Kanji et al. (2011) are from the University of Toronto continuous flow diffusion chamber. The magenta and dotted lines represent the same parameters as in Fig. 2. Note that the magenta line is only valid for the wood burning and diesel particles data points.

therefore reasonable to conclude that diesel and wood burning particles are poorer IN than mineral dust in the temperature range studied.

\subsection{Comparison with other studies involving organic coating}

Investigation of the effect of organic coatings on ice nucleation ability of mineral dusts has been conducted in previous laboratory studies (Möhler et al., 2008), as well as on soot particles (Friedman et al., 2011) and atmospheric particles (Knopf et al., 2010). Möhler et al. (2008) showed that an oxidized $\alpha$-pinene coating on ATD particles strongly decreases the IN ability of the particles in the deposition nucleation mode. Their results are opposite to our study where the oxidized $\alpha$-pinene coating lead to an ice nucleation enhancement. A reason of the difference could be attributed to the fact that the ice formation mode observed in Möhler et al. (2008) was deposition nucleation at temperatures between $-63^{\circ} \mathrm{C}$ and $-68^{\circ} \mathrm{C}$ while in our coating experiment the investigation was conducted at significantly higher temperature $\left(-35^{\circ} \mathrm{C}\right)$ and we observe the enhancement in the condensation mode. It is possible, that the oxidized coating is enhancing water uptake onto the particles thus favouring an earlier onset of ice formation compared to the uncoated particles (Fig. 6a).

Friedman et al. (2011) performed experiments on monodisperse soot produced from a miniCAST Real Soot Generator (Jing Ltd.). The effect of different acid coatings 
(malic, adipic, oleic) on the ice nucleation behaviour of the particles at $-30,-35$ and $-40^{\circ} \mathrm{C}$ have been reported. Their results show that no ice was observed at -30 and $-35^{\circ} \mathrm{C}$ with and without coatings. However it is likely due to the fact that the evaporation section of their CFDC is very short and does not allow higher $\mathrm{RH}_{\mathrm{w}}$ to be achieved in the growth section before droplets are detected. At $-40^{\circ} \mathrm{C}$, they have found similar behaviour as in our study inferring that homogeneous freezing might be the main mechanism at this temperature.

Knopf et al. (2010) have shown that anthropogenic organic coatings did not affect the ice nucleation behaviour of ambient atmospheric particles collected in an urban region (Mexico City). This would agree with the main results of our experiments except for experiment $15 \mathrm{~d}$. This exception also suggests that using laboratory proxies to produce organic coatings can result in different ice nucleation behaviour compared to atmospherically relevant organic coatings.

\section{Conclusions}

Investigation of the ice nucleation properties of diesel and wood burning particles were conducted from 17 August to 23 September 2009 at the Paul Scherrer Institute smog chamber. The first set of results showed that the ice nucleation ability of the particles did not differ as a function of the burning phase or diesel vehicle type investigated. Furthermore, the results showed that for diesel particles, ice formation took place only at temperatures as low as $-40^{\circ} \mathrm{C}$ by deposition nucleation. Wood burning particles did nucleate ice above water saturation at $-35^{\circ} \mathrm{C}$ via condensation freezing and via deposition nucleation at $-40^{\circ} \mathrm{C}$, below water saturation. Ice nucleation investigations of the photochemically aged diesel and wood burning particles were conducted. Results show that photochemical ageing did not result in any significant changes in the ice nucleation ability of the particles, unlike previous studies that showed that sulphuric acid coating either enhanced (DeMott et al., 1999) or decreased (Möhler et al., 2005a) the ice nucleation onset of soot particles. Photochemical ageing from the gas phase of the particle's own exhaust could lead to the lack of uniform coating and could be the explanation as to why no difference in ice nucleation was observed between fresh and aged particles. This assumption is confirmed by experiment $15 \mathrm{~d}$ where a thicker coating after addition of $\alpha$-pinene led to a larger particle size, a higher $\mathrm{OC}: \mathrm{BC}$ ratio and a better IN ability. From the flaming phase experiments, it appeared that the $\mathrm{OC}: \mathrm{BC}$ ratio is clearly not the governing factor in our experiments for ice nucleation as these particles form ice at $-35^{\circ} \mathrm{C}$ despite their low OC: $\mathrm{BC}$ ratio (0.1 to 0.5 ). Regarding experiment $15 \mathrm{~d}$ (where adding an $\alpha$-pinene coating resulted in a significant particle size increase), size is probably of high importance for the better IN ability but other parameters that have not been investigated like the functional groups at the surface or/and particle shape could also be of significant contribution.
Wood burning and diesel combustion particles are emitted in the atmosphere in very high concentrations which make them a potential source of IN at mixed phase cloud levels. Our study has shown that ice formation could not be observed at $-30^{\circ} \mathrm{C}$ but is observable in some cases at $-35^{\circ} \mathrm{C}$ for fresh and photochemically aged particles at typical mixed phase cloud conditions. Photo-oxidation of the particles was performed at atmospherically relevant conditions in the PSI smog chamber but no modification of the IN ability on the particles was observed. It is therefore possible to conclude that diesel and wood burning particles do not play a significant role in heterogeneous ice formation at mixed phase clouds temperatures in comparison to mineral dust. It would nevertheless be worthwhile to investigate the effect of photochemistry onto diesel and wood burning particles at temperatures below $-40^{\circ} \mathrm{C}$ in order to see if this has an impact for colder clouds.

Acknowledgements. We acknowledge the support by the IMBALANCE project of the Competence Center Environment and Sustainability of the ETH Domain (CCES). We also acknowledge Hannes Wydler for the various technical help provided on the instrument. We thank Welti for the scientific discussion.

Edited by: A. Kiendler-Scharr

\section{References}

Aiken, A. C., DeCarlo, P. F., Kroll, J. H., Worsnop, D. R., Huffman, J. A., Docherty, K. S., Ulbrich, I. M., Mohr, C., Kimmel, J. R., Sueper, D., Sun, Y., Zhang, Q., Trimborn, A., Northway, M., Ziemann, P. J., Canagaratna, M. R., Onasch, T. B., Alfarra, M. R., Prévôt, A. S. H., Dommen, J., Duplissy, J., Metzger, A., Baltensperger, U., and Jimenez, J. L.: O/C and OM/OC ratios of primary, secondary, and ambient organic aerosols with high-resolution time-of-flight aerosol mass spectrometry, Environ. Sci. Technol., 42, 4478-4485, 2008.

Chirico, R., DeCarlo, P. F., Heringa, M. F., Tritscher, T., Richter, R., Prévôt, A. S. H., Dommen, J., Weingartner, E., Wehrle, G., Gysel, M., Laborde, M., and Baltensperger, U.: Impact of aftertreatment devices on primary emissions and secondary organic aerosol formation potential from in-use diesel vehicles: results from smog chamber experiments, Atmos. Chem. Phys., 10, 11545-11563, doi:10.5194/acp-10-11545-2010, 2010.

Chou, C., Stetzer, O., Weingartner, E., Jurányi, Z., Kanji, Z. A., and Lohmann, U.: Ice nuclei properties within a Saharan dust event at the Jungfraujoch in the Swiss Alps, Atmos. Chem. Phys., 11, 4725-4738, doi:10.5194/acp-11-4725-2011, 2011.

Cozic, J., Mertes, S., Verheggen, B., Cziczo, D. J., Gallavardin, S. J., Walter, S., Baltensperger, U., and Weingartner, E.: Black carbon enrichment in atmospheric ice particle residuals observed in lower tropospheric mixed phase clouds, J. Geophys. Res., 113, D15209, doi:10.1029/2007JD009266, 2008.

DeMott, P. J., Chen, Y., Kreidenweis, S. M., Rogers, D. C., and Sherman, D. E.: Ice formation by black carbon particles, Geophys. Res. Lett., 26, 2429-2432, doi:10.1029/1999GL900580, 1999. 
DeMott, P. J., Petters, M. D., Prenni, A. J., Carrico, C. M., Kreidenweis, S. M., Collett Jr, J. L., and Moosmüller, H.: Ice nucleation behavior of biomass combustion particles at cirrus temperatures, J. Geophys. Res., 114, D16205, doi:10.1029/2009JD012036, 2009.

Demott, P. J., Möhler, O., Stetzer, O., Vali, G., Levin, Z., Petters, M. D., Murakami, M., Leisner, T., Bundke, U., Klein, H., et al.: Resurgence in ice nuclei measurement research, B. Am. Meteorol. Soc., 92, 1623-1635, 2011.

Denman, K. L., Brasseur, G., Chidthaisong, A., Ciais, P., Cox, P. M., Dickinson, R. E., Hauglustaine, D., Heinze, C., Holland, E., Jacob, D., et al.: Couplings between changes in the climate system and biogeochemistry, Clim. change, 499-587, 2007.

Dymarska, M., Murray, B. J., Sun, L., Eastwood, M. L., Knopf, D. A., and Bertram, A. K.: Deposition ice nucleation on soot at temperatures relevant for the lower troposphere, J. Geophys. Res.-Atmos., 111, D04204, doi:10.1029/2005JD006627, 2006.

Ebert, M., Worringen, A., Benker, N., Mertes, S., Weingartner, E., and Weinbruch, S.: Chemical composition and mixing-state of ice residuals sampled within mixed phase clouds, Atmos. Chem. Phys., 11, 2805-2816, doi:10.5194/acp-11-2805-2011, 2011.

Fornea, A. P., Brooks, S. D., Dooley, J. B., and Saha, A.: Heterogeneous freezing of ice on atmospheric aerosols containing ash, soot, and soil, J. Geophys. Res, 114, D13201, doi:10.1029/2009JD011958, 2009.

Friedman, B., Kulkarni, G., Beránek, J., Zelenyuk, A., Thornton, J. A., and Cziczo, D. J.: Ice nucleation and droplet formation by bare and coated soot particles, J. Geophys. Res., 116, D17203, doi:10.1029/2011JD015999, 2011.

Hansen, J., Sato, M., and Ruedy, R.: Radiative forcing and climate response, J. Geophys. Res., 102, 6831-6864, 1997.

Heringa, M. F., DeCarlo, P. F., Chirico, R., Tritscher, T., Dommen, J., Weingartner, E., Richter, R., Wehrle, G., Prévôt, A. S. H., and Baltensperger, U.: Investigations of primary and secondary particulate matter of different wood combustion appliances with a high-resolution time-of-flight aerosol mass spectrometer, Atmos. Chem. Phys., 11, 5945-5957, doi:10.5194/acp-11-59452011, 2011.

Hoose, C., Lohmann, U., Erdin, R., and Tegen, I.: The global influence of dust mineralogical composition on heterogeneous ice nucleation in mixed-phase clouds, Environ. Res. Lett., 3, 025003, doi:10.1088/1748-9326/3/2/025003, 2008.

Kamphus, M., Ettner-Mahl, M., Klimach, T., Drewnick, F., Keller, L., Cziczo, D. J., Mertes, S., Borrmann, S., and Curtius, J.: Chemical composition of ambient aerosol, ice residues and cloud droplet residues in mixed-phase clouds: single particle analysis during the Cloud and Aerosol Characterization Experiment (CLACE 6), Atmos. Chem. Phys., 10, 8077-8095, doi:10.5194/acp-10-8077-2010, 2010.

Kanji, Z. A., DeMott, P. J., Möhler, O., and Abbatt, J. P. D.: Results from the University of Toronto continuous flow diffusion chamber at ICIS 2007: instrument intercomparison and ice onsets for different aerosol types, Atmos. Chem. Phys., 11, 31-41, doi:10.5194/acp-11-31-2011, 2011.

Kärcher, B., Möhler, O., DeMott, P. J., Pechtl, S., and Yu, F.: Insights into the role of soot aerosols in cirrus cloud formation, Atmos. Chem. Phys., 7, 4203-4227, doi:10.5194/acp-7-4203-2007, 2007.
Knopf, D. A., Wang, B., Laskin, A., Moffet, R. C., and Gilles, M. K.: Heterogeneous nucleation of ice on anthropogenic organic particles collected in Mexico City, Geophys. Res. Lett., 37, L11803 , 2010.

Koehler, K. A., DeMott, P. J., Kreidenweis, S. M., Popovicheva, O. B., Petters, M. D., Carrico, C. M., Kireeva, E. D., Khokhlova, T. D., and Shonija, N. K.: Cloud condensation nuclei and ice nucleation activity of hydrophobic and hydrophilic soot particles, Phys. Chem. Chem. Phys., 11, 7906-7920, 2009.

Koop, T.: Homogeneous ice nucleation in water and aqueous solutions, Zeitschr. f. Phys. Chem./Int. J. Res. Phys. Chem. Chem. Phys., 218, 1231-1258, 2004.

Koop, T., Luo, B., Tsias, A., and Peter, T.: Water activity as the determinant for homogeneous ice nucleation in aqueous solutions, Nature, 406, 611-614, 2000.

Koren, I., Kaufman, Y. J., Remer, L. A., and Martins, J. V.: Measurement of the effect of Amazon smoke on inhibition of cloud formation, Science, 303, 1342, doi:10.1126/science.1089424, 2004.

Lin, J. C., Matsui, T., Pielke Sr, R. A., and Kummerow, C.: Effects of biomass-burning-derived aerosols on precipitation and clouds in the Amazon Basin: a satellite-based empirical study, J. Geophys. Res, 111, D19204, doi:10.1029/2005JD006884 2006.

Lipsky, E. M. and Robinson, A. L.: Effects of dilution on fine particle mass and partitioning of semivolatile organics in diesel exhaust and wood smoke, Environ. Sci. Technol., 40, 155-162, 2006.

Lohmann, U. and Hoose, C.: Sensitivity studies of different aerosol indirect effects in mixed-phase clouds, Atmos. Chem. Phys., 9, 8917-8934, doi:10.5194/acp-9-8917-2009, 2009.

Martin, M., Tritscher, T., Jurányi, Z., Heringa, M. F., Sierau, B., Weingartner, E., Chirico, R., Gysel, M., Prévôt, A. S. H., Baltensperger, U., and Lohmann, U.: Hygroscopic properties of fresh and aged wood burning particles, J. Aerosol Sci., 56, 1529, doi:10.1016/j.jaerosci.2012.08.006, 2012.

McDonald, J. D., Zielinska, B., Fujita, E. M., Sagebiel, J. C., Chow, J. C., and Watson, J. G.: Fine particle and gaseous emission rates from residential wood combustion, Environ. Sci. Technol., 34, 2080-2091, 2000.

Möhler, O., Büttner, S., Linke, C., Schnaiter, M., Saathoff, H., Stetzer, O., Wagner, R., Krämer, M., Mangold, A., Ebert, V., et al.: Effect of sulfuric acid coating on heterogeneous ice nucleation by soot aerosol particles, J. Geophys. Res., 110, D11210, doi:10.1029/2004JD005169, 2005a.

Möhler, O., Linke, C., Saathoff, H., Schnaiter, M., Wagner, R., Mangold, A., Krämer, M., and Schurath, U.: Ice nucleation on flame soot aerosol of different organic carbon content, Meteorol Zeitschr., 14, 477-484, 2005b.

Möhler, O., Benz, S., Saathoff, H., Schnaiter, M., Wagner, R., Schneider, J., Walter, S., Ebert, V., and Wagner, S.: The effect of organic coating on the heterogeneous ice nucleation efficiency of mineral dust aerosols, Environ. Res. Lett., 3, 025007, doi:10.1088/1748-9326/3/2/025007, 2008.

Paulsen, D., Dommen, J., Kalberer, M., Prévôt, A. S. H., Richter, R., Sax, M., Steinbacher, M., Weingartner, E., and Baltensperger, U.: Secondary Organic Aerosol Formation by Irradiation of 1,3,5Trimethylbenzene- $\mathrm{NO}_{\mathrm{x}}-\mathrm{H}_{2} \mathrm{O}$ in a New Reaction Chamber for Atmospheric Chemistry and Physics, Environ. Sci. Technol, 39, 2668-2678, 2005. 
Petters, M. D., Parsons, M. T., Prenni, A. J., DeMott, P. J., Kreidenweis, S. M., Carrico, C. M., Sullivan, A. P., McMeeking, G. R., Levin, E., Wold, C. E., Collett Jr., J. L., and Moosmüller, H.: Ice nuclei emissions from biomass burning, J. Geophys. Res., 114, D07209, doi:10.1029/2008JD011532, 2009.

Schauer, J. J., Kleeman, M. J., Cass, G. R., and Simoneit, B. R. T.: Measurement of emissions from air pollution sources. 3. C1-C29 organic compounds from fireplace combustion of wood, Environ. Sci. Technol., 35, 1716-1728, 2001.

Schauer, J. J., Kleeman, M. J., Cass, G. R., and Simoneit, B. R. T.: Measurement of emissions from air pollution sources. 5. C1C32 organic compounds from gasoline-powered motor vehicles, Environ. Sci. Technol., 36, 1169-1180, 2002.

Storelvmo, T., Kristjánsson, J. E., and Lohmann, U.: Aerosol influence on mixed-phase clouds in CAM-Oslo, J. Atmos. Sci., 65, 3214-3230, 2008.

Sullivan, R. C., Miñambres, L., DeMott, P. J., Prenni, A. J., Carrico, C. M., Levin, E. J. T., and Kreidenweis, S. M.: Chemical processing does not always impair heterogeneous ice nucleation of mineral dust particles, Geophys. Res. Lett., 37, L24805, doi:10.1029/2010GL045540, 2010.

Targino, A. C., Coe, H., Cozic, J., Crosier, J., Crawford, I., Bower, K., Flynn, M., Gallagher, M., Allan, J., Verheggen, B., Baltensperger, U., and Chourlaton, T.: Influence of particle chemical composition on the phase of cold clouds at a high-alpine site in Switzerland, J. Geophys. Res., 114, D18206, doi:10.1029/2008JD011365, 2009.
Tritscher, T., Jurányi, Z., Martin, M., Chirico, R., Gysel, M., Heringa, M. F., DeCarlo, P. F., Sierau, B., Prévôt, A. S. H., Weingartner, E., et al.: Changes of hygroscopicity and morphology during ageing of diesel soot, Environ. Res. Lett., 6, 034026, doi:10.1088/1748-9326/6/3/034026, 2011.

Vali, G.: Nucleation terminology, B. Am. Meteor. Soc, 66, 14261427, 1985.

Weingartner, E., Saathoff, H., Schnaiter, M., Streit, N., Bitnar, B., and Baltensperger, U.: Absorption of light by soot particles: determination of the absorption coefficient by means of aethalometers, J. Aerosol Sci., 34, 1445-1463, 2003.

Zelenay, V., Mooser, R., Tritscher, T., Krepelová, A., Heringa, M. F., Chirico, R., Prévôt, A. S. H., Weingartner, E., Baltensperger, U., Dommen, J., et al.: Aging induced changes on NEXAFS fingerprints in individual combustion particles, Atmos. Chem. Phys., 11, 11777-11791, doi:10.5194/acp-11-11777-2011, 2011. 